Short Communication

\title{
Charge Transport Improvement in Nafion Membrane by Simoultaneous Microwave Synthesis and Deposition of YSZ
}

\author{
Agustin Barón ${ }^{1}$, E. Valenzuela ${ }^{2}$, Rafael Sánchez ${ }^{1}$, A. G. González-Gutiérrez ${ }^{1}$ and P.J. Sebastian, ${ }^{1, *}$ \\ ${ }^{1}$ Instituto de Energías Renovables-UNAM, Temixco, Morelos, 62580, México. \\ ${ }^{2}$ Facultad de Ingeniería, UABC Mexicali, Blvd. Benito Juárez y calle de la Normal Col. Insurgentes \\ Este, 21280, México. \\ *E-mail: sjp@ier.unam.mx
}

doi: $10.20964 / 2016.09 .46$

Received: 15 March 2016 / Accepted: 18 June 2016 / Published: 7 August 2016

\begin{abstract}
The improvement of water retention properties of Nafion membranes is a key feature that could simplify its operation and increase the reliability of Proton Exchange Membrane Fuel Cells (PEMFC). In this work, nanostructured YSZ was synthesized in a microwave reactor and their properties were evaluated by TEM and XRD. After characterization, YSZ was deposited on Nafion membranes by three different methods, including a novel simultaneous YSZ synthesis/deposition on Nafion as an attempt to simplify the process and to improve the effectiveness of the deposition of the material in the membrane. The water retention properties of the modified membranes were evaluated and compared with un-modified Nafion. Their electrochemical properties were characterized by Electrochemical Impedance Spectroscopy (EIS) to determine the relationship between the YSZ deposition, the water retention and its protonic charge conductivity. The evaluations have shown that membranes modified with YZS exhibited higher water retention. Furthermore, the YSZ modified membranes showed an important diminution in their charge transfer resistance compared to commercial Nafion.
\end{abstract}

Keywords: YSZ; Nafion charge transport; EIS characterization; PEMFC

\section{FULL TEXT}

(C) 2016 The Authors. Published by ESG (www.electrochemsci.org). This article is an open access article distributed under the terms and conditions of the Creative Commons Attribution license (http://creativecommons.org/licenses/by/4.0/). 